\title{
Fatal, virus-associated peripheral neuropathy and retinopathy in farmed Penaeus monodon in eastern Australia. I. Pathology
}

\author{
R. B. Callinan ${ }^{1, *}$, L. Jiang ${ }^{1}$, P. T. Smith ${ }^{2}$, C. Soowannayan ${ }^{3}$ \\ ${ }^{1}$ New South Wales Fisheries, Aquatic Animal Health Unit, Regional Veterinary Laboratory, Wollongbar, \\ New South Wales 2477, Australia \\ ${ }^{2}$ Centre for Sustainable Aquaculture, University of Western Sydney, Campbelltown, New South Wales 2560, Australia \\ ${ }^{3}$ Centex Shrimp, Faculty of Science, Mahidol University, Rama 6 Road, Bangkok 10400, Thailand
}

\begin{abstract}
Lesions are described in farmed Penaeus monodon affected with a previously unreported, fatal disease, 'peripheral neuropathy and retinopathy' (PNR). Outbreaks, associated with minor to heavy mortalities, occurred in 22 of 25 ponds on a farm in eastern Australia during the mid to late 1998/99 growout period. Moribund prawns, 5 to $26 \mathrm{~g}$ mean body weight, gathered at pond edges and were typically reddish in colour, lethargic, with mild to moderate epibiotic fouling and 1 or more partially amputated appendages. Histologically, there was mild to severe, focal to diffuse degeneration and necrosis of axons and their sheaths, together with associated glial cell apoptosis, in peripheral nerve fibres. Of the 3 appendage types examined systematically, these pathognomonic lesions were most common and severe in proximal antennal nerves and less common and severe in distal antennal nerves, antennular nerves and pereiopod nerves. Mild to severe, acute to chronic retinitis, associated with degeneration and necrosis of retinular cells and their axons, was also present in most clinically affected prawns. Transmission electron microscopy revealed moderate to large numbers of intracytoplasmic rod-shaped, helical nucleocapsids and enveloped virions, morphologically consistent with a yellow head-like virus, in putative glial cells in the antennal nerve, in the fasciculated zone of the eye and in putative sensory nerve cells of antennules. Immunohistochemical examination revealed lesions, but not histologically normal tissues, in peripheral nerves, eyes, lymphoid organ and vas deferens that consistently stained positively for a yellow head-related virus. The findings strongly suggest that a yellow head-related virus such as the Australian gill-associated virus (GAV) is causally associated with PNR. It is likely that PNR was not recognised during earlier investigations of mid-crop mortalities of farmed P. monodon in eastern Australia because appropriate peripheral nerves and eyes were not routinely examined histologically.
\end{abstract}

KEY WORDS: Penaeus monodon $\cdot$ Neuropathy $\cdot$ Retinopathy $\cdot$ GAV $\cdot$ PNR $\cdot$ MCMS

\section{INTRODUCTION}

Prior to 1994, farmed prawn populations in Australia appeared free of the major disease-related losses reported from elsewhere in the Asia-Pacific region. Subsequently, however, significant losses occurring in the second half of the growout period on Australian Penaeus monodon farms have often been attributed to a new condition, designated 'mid-crop mortality syndrome' (MCMS) by farmers. Two viruses, a rod-shaped virus designated 'gill-associated virus' (GAV) and a parvo-like virus very similar or identical to spawnerisolated mortality virus (SMV) have been proposed as causes of MCMS (Munday \& Owens 1998). However, until recently, only non-specific clinical signs and gross pathological changes, together with minor histopathological lesions have been reported from prawns naturally or experimentally infected with either of these viruses or from disease outbreaks otherwise attributed to MCMS (Spann et al. 1997, Young 1997, Munday \& 
Owens 1998). This absence of lesions to which observed clinical signs could be attributed has raised questions about the significance of either virus in MCMS. However, Smith (2000) described degenerative and necrotic lesions associated with a GAV-like virus in eyes of moribund $P$. monodon collected from Australian farms, thereby providing some additional support for a causal role for GAV in disease outbreaks consistent with MCMS.

In this paper we describe severe lesions, principally in peripheral nerves and eyes, in farmed Penaeus monodon collected during pond-level outbreaks of a disease, designated 'peripheral neuropathy and retinopathy' (PNR). This disease was clinically consistent with MCMS, and a yellow head-related virus was consistently present in lesions. Since GAV is the only yellow head-related virus so far reported in Australia (Cowley et al. 1999), the virus may be GAV or related to it. The epidemiology of the outbreak has been described separately (Callinan \& Jiang 2003, this issue).

\section{MATERIALS AND METHODS}

An outbreak of disease in Penaeus monodon during the 1998/99 growout period was investigated on a prawn farm comprising 25 ponds, each 0.5 to 1.5 ha in surface area, on the lower Clarence River, New South Wales, Australia $\left(29^{\circ} 25^{\prime} \mathrm{S}, 153^{\circ} 21^{\prime} \mathrm{E}\right)$. Ponds were stocked in late October and harvested between March and May of the following year. From mid-January 1999, farm staff reported large numbers (usually 25 to 50) of moribund or dead prawns present daily at the edges of one of the ponds. Subsequently, in the period to mid-April, prawns in all but 3 of the remaining ponds became similarly affected; ponds were designated 'affected' if at least 10 typically affected, moribund prawns per day were seen consistently at the pond edges. Cumulative mortalities attributed to the disease in affected ponds ranged from 0 to $50 \%$ (Callinan \& Jiang 2003).

Histopathology. Typically affected, moribund prawns were collected from pond edges, fixed for 24 to $72 \mathrm{~h}$ in Davidson's fixative using standard methods (Bell \& Lightner 1988) and stored subsequently in 50\% ethanol. In the early stages of the investigation, specimens from each prawn were prepared for histopathological examination using the 'gut-gill panorama' method of Bell \& Lightner (1988), embedded in paraffin wax, sectioned at $4 \mu \mathrm{m}$ and stained with haematoxylin and eosin (H\&E). Later, when the pattern of lesion distribution was better recognised, the method was modified in most cases to ensure that supraoesophageal ganglion, antennules, antennal nerve root, antennae, pereiopods and eyes, as well as other major organs, were sectioned. In the remaining cases, only supraoesophageal ganglion, antennae, pereiopods and/or eyes were sectioned. In addition to these moribund prawns, clinically normal prawns with minor macroscopic abormalities apparently unrelated to PNR (such as blue cuticle) were collected by cast net from Ponds 9, 24, 25 and 26, $7 \mathrm{wk}$ before outbreaks were recognised in those ponds, and were similarly prepared for histopathological examination. In a separate exercise to examine the possibility that nerve lesions in appendages were a consequence of partial amputation, intact antennules, antennae and paired, intact and partially amputated pereiopods from moribund prawns were prepared for histopathological examination as above.

Immumohistochemistry. Sections of prawns prepared as described above and showing representative lesions were used for immunohistochemical examination with 2 monoclonal antibodies (MAb) (Clones Y-18 and Y-19) reactive against a 67 and $22 \mathrm{kDa}$ protein of yellow head virus (YHV), respectively (Sithigorngul et al. 2002); these MAb have been shown to cross react with GAV (Soowannayan unpubl. data). Briefly, using the methods of Sithigorngul et al. (2000), sections were first de-waxed in xylene, re-hydrated in ethanol series to water and blocked with $\mathrm{P} 1^{+}(10 \%$ fetal calf serum in PBS). They were covered with culture fluid of the hybridoma clones Y-18 or Y-19, diluted 1:5 in $\mathrm{P} 1^{+}$and incubated in a moist chamber at $37^{\circ} \mathrm{C}$ for $30 \mathrm{~min}$. They were then washed with PBS before being covered with horseradish peroxidase-labelled goat anti-mouse IgG heavy and light chain-specific (GAM-HRP; Biorad) and incubated in a moist chamber at $37^{\circ} \mathrm{C}$ for $30 \mathrm{~min}$. Samples were then washed with PBS and covered with the mixture substrate, $\mathrm{H}_{2} \mathrm{O}_{2}$ and chromagen, diaminobenzidine $(\mathrm{DAB})$ in $\mathrm{PBS}$ to reveal peroxidase activity, washed and counter stained with H\&E, dehydrated, mounted and examined with a light microscope. A brown color constituted a positive reaction to the MAb.

Transmission electron microscopy. Portions of antennules, supraoesophageal ganglia including antennal nerve roots and eyes from moribund prawns were diced and fixed in $4 \%$ glutaraldehyde in $0.15 \mathrm{M}$ phosphate buffer (Lightner 1996). Tissues were postfixed in $1 \%$ osmium tetroxide, dehydratred through a graded series of ethanol concentrations and fixed in Epon resin. Sections were cut at 50 to $60 \mathrm{~nm}$, mounted on $\mathrm{Cu}-200$ copper grids, stained with uranyl acetate in $50 \%$ methanol and Reynolds lead citrate and examined at $80 \mathrm{kV}$ under a Jeol 1010 TEM.

Bacteriology. Samples of haemolymph were collected aseptically from 5 typically affected moribund prawns and inoculated onto TCBS agar. Cultures were incubated at room temperature (ca. $22^{\circ} \mathrm{C}$ ) for $2 \mathrm{~d}$ and examined for evidence of Vibrio-like bacteria. 


\section{RESULTS}

\section{Clinical signs and gross pathology}

Moribund Penaeus monodon gathered at pond edges and were often reddish in colour and lethargic, with one or more partially amputated appendages, erosion and melanisation of uropod margins and mild to moderate epibiotic fouling.

\section{Histopathology}

In individual prawns, lesions were typically present in peripheral nerves, eyes, supraoesophageal ganglion, lymphoid organ and, if male, vas deferens.

\section{Peripheral nerves}

Axons and sheaths of nerve fibres were affected. Small to large numbers of mildly to severely affected fibres were in most cases diffusely distributed within nerves, but lesions occasionally appeared restricted to fibres within particular fascicles and absent from others. In mildly affected fibres, there was localised swelling and increased granularity of axons together with vacuolation of their sheaths. Associated glial cells appeared apoptotic, with nuclei condensed into characteristic, basophilic spheres sometimes surrounded by a narrow rim of condensed cytoplasm. More severely affected fibres consisted of longitudinally contiguous, ovoid vacuolated sheaths containing fragmented axonal remnants and apoptotic glial cells (Figs. 1 to 3). In most cases these typically subspherical nuclear remnants appeared isolated within lesions, but occasionally they were visible immediately adjacent to apparently healthy nuclei, possibly as intracytoplasmic inclusions. Both small and medium-sized axons were affected, whereas giant (motor) axons always appeared normal. Mild to moderate vascular dilation was often present in affected areas, with margination and infiltration of small to moderate numbers of haemocytes (Fig. 4). There was no evidence of glial cell proliferation, axonal sprouting or other signs of repair.

Some distally located sensory neurons in antennae or antennules with affected nerves appeared shrunken, with pyknotic, marginated nuclei and darkly eosinophilic cytoplasm, suggesting degeneration and necrosis.

Of the 3 appendage types examined systematically, lesions were most common and severe in proximal

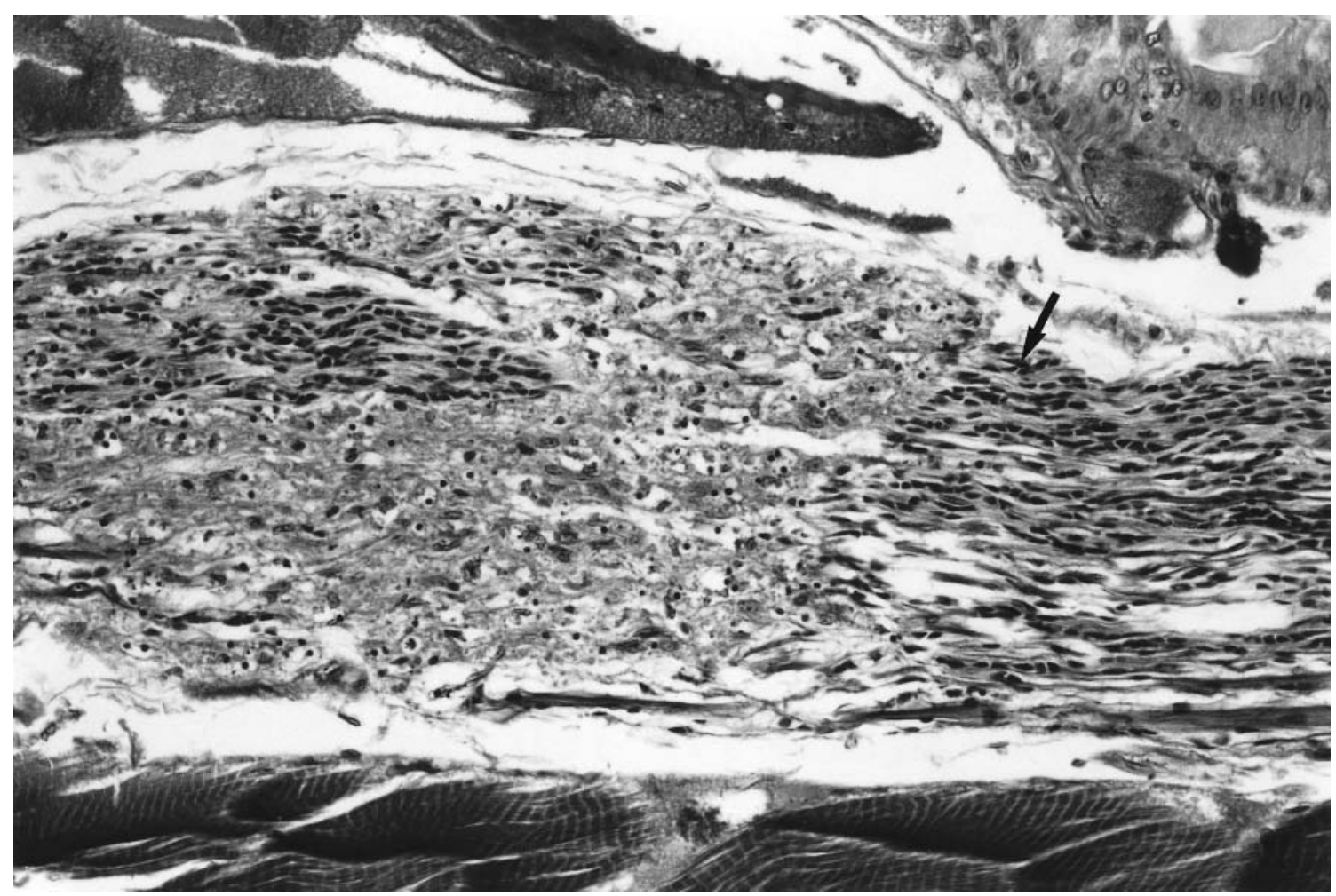

Fig. 1. Penaeus monodon. Peripheral neuropathy, showing severe, locally extensive degeneration and necrosis of nerve fibres and associated glial cells in a pereiopod. Note apparently normal fibres (arrow) on the margins of the lesion $(\mathrm{H} \& \mathrm{E}, \times 300)$ 


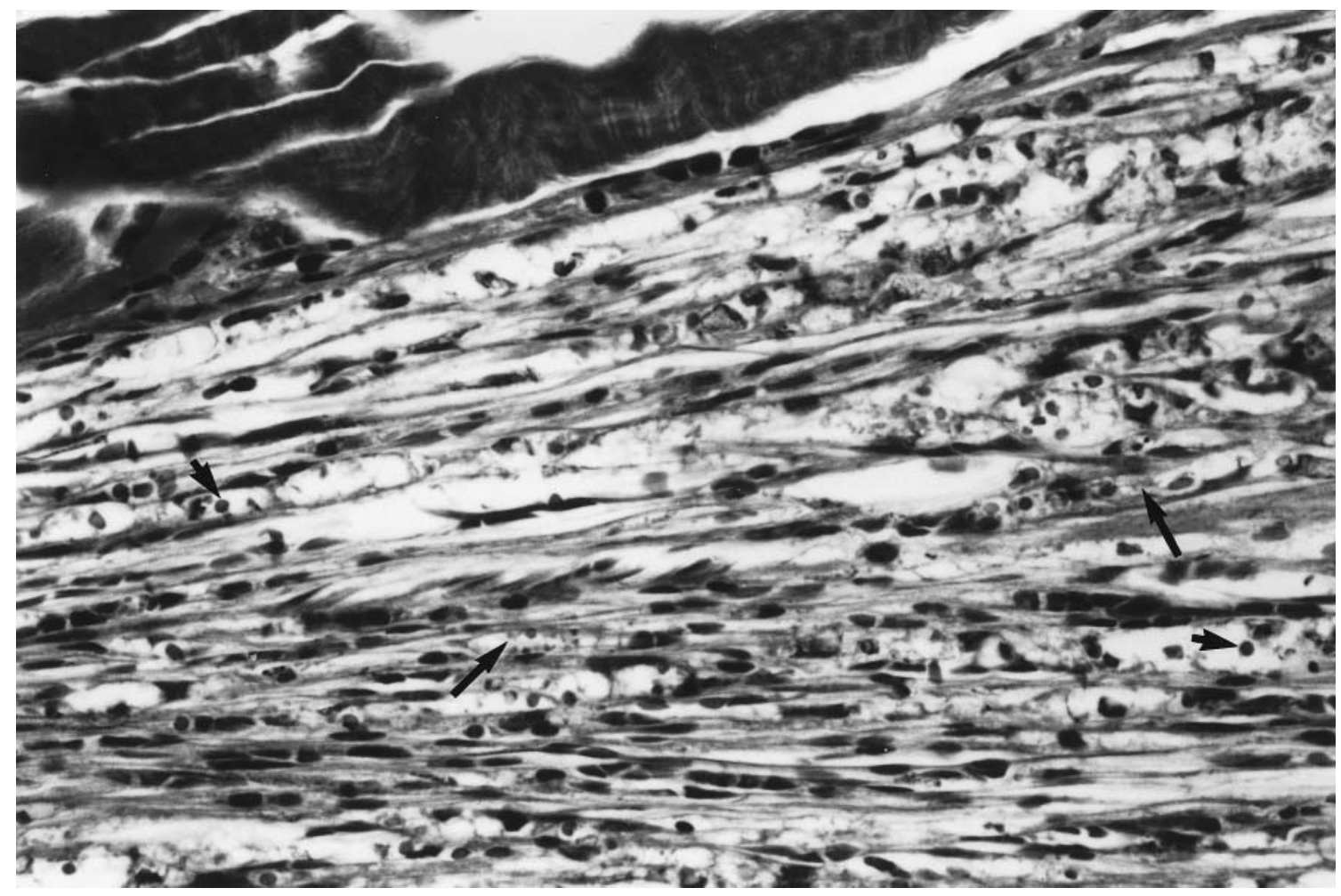

Fig. 2. Penaeus monodon. Peripheral neuropathy, showing necrosis and fragmentation of axons and vacuolation of axon sheaths (long arrows) in antennal nerve fibres. Apoptotic glial cell remnants (short arrows) are also present in vacuolated areas. (H\&E, $\times 600)$

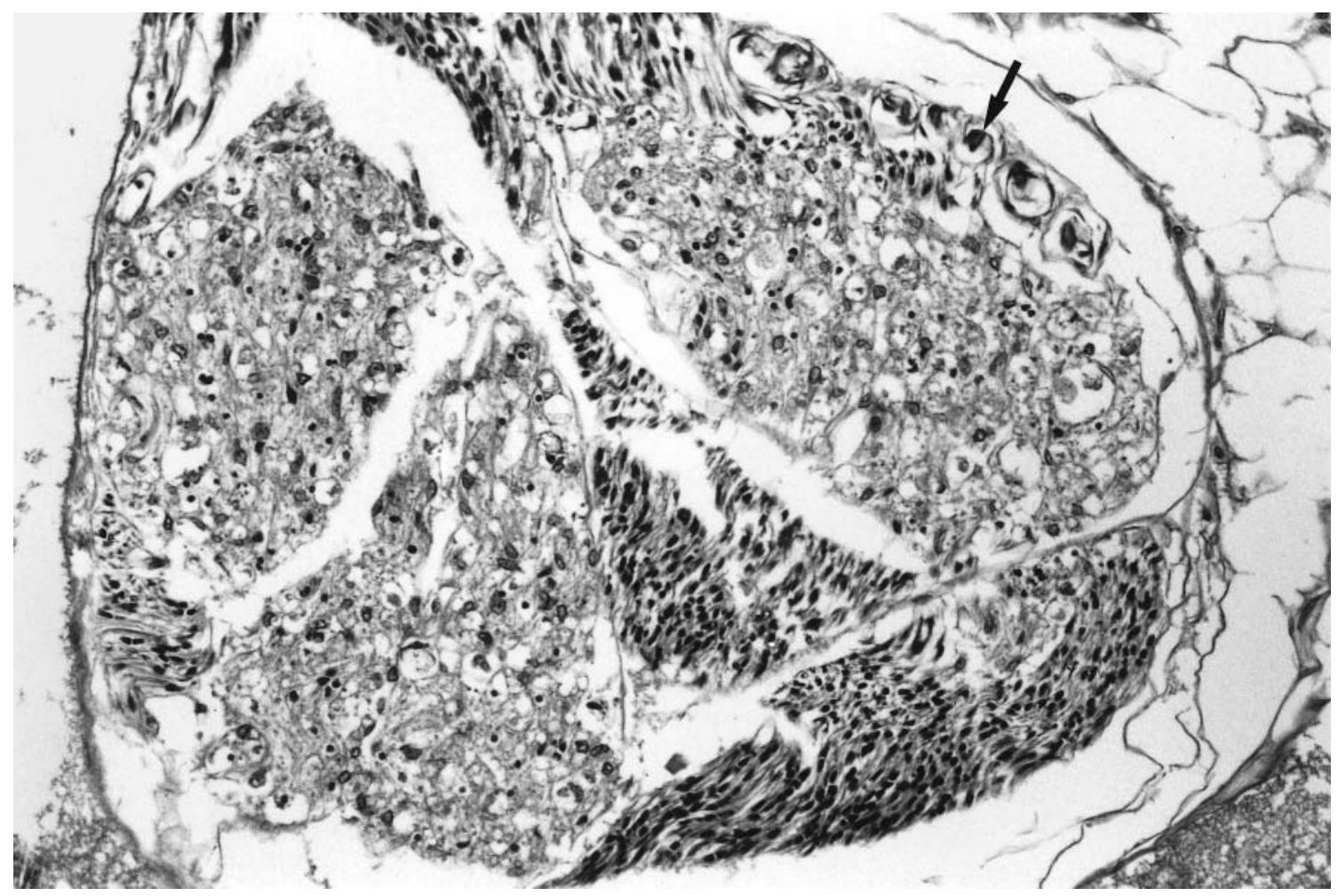

Fig. 3. Penaeus monodon. Peripheral neuropathy. Cross section of a pereiopod nerve showing substantial lesion confinement within fascicles. Note that giant motor fibres (arrow) appear normal $(\mathrm{H} \& \mathrm{E}, \times 300)$ 


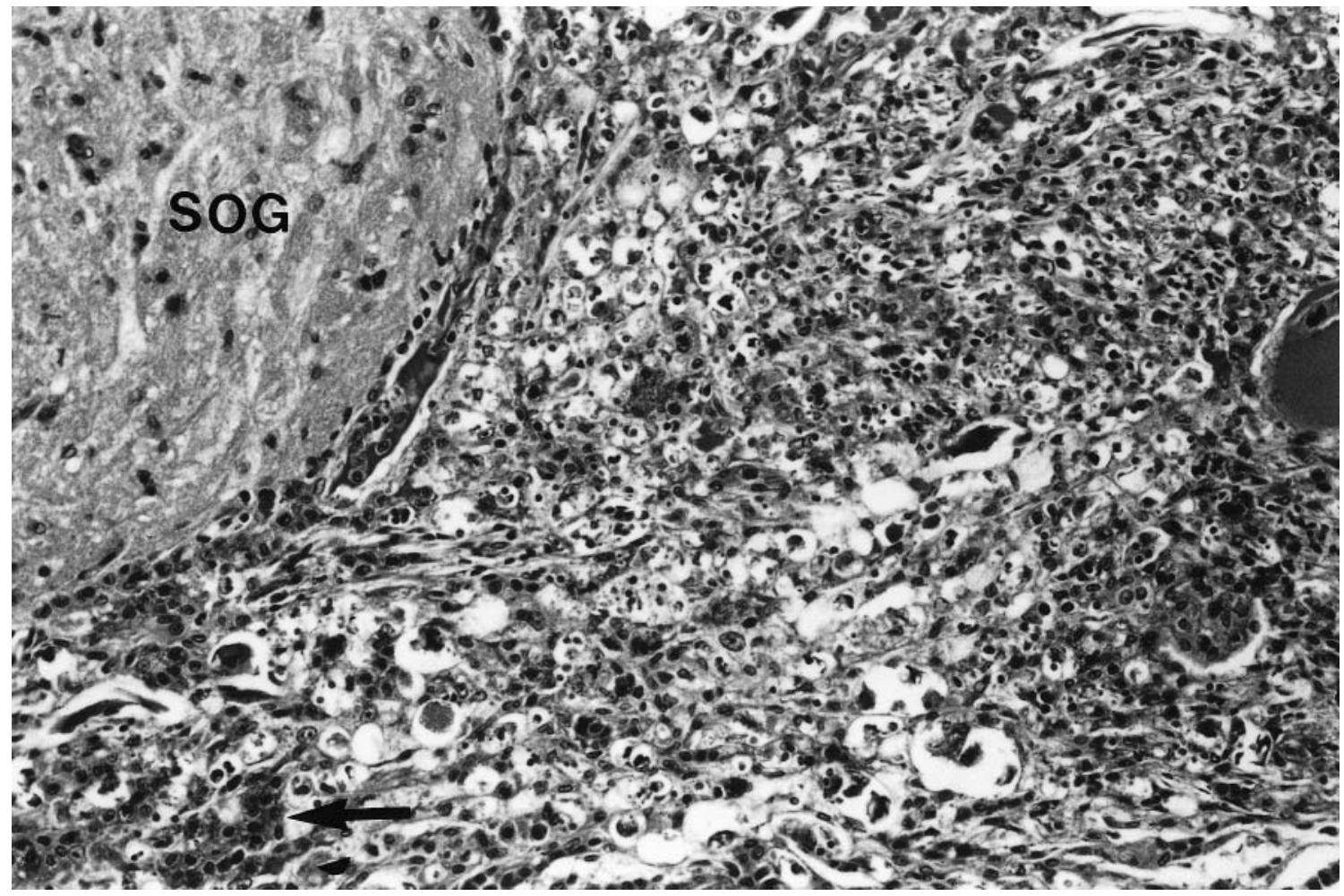

Fig. 4. Penaeus monodon. Peripheral neuropathy, showing severe, subacute neuropathy in antennal nerve adjacent to supraoesophageal ganglion (SOG), with mild to moderate vascular dilation and accumulations of haemocytes (arrow) in affected areas. Very few normal antennal nerve fibres are visible (H\&E, ×600)

antennal nerves (i.e. within the cephalothorax, close to the supraoesophageal ganglion) and less common and severe in distal antennal nerves (i.e. within the antenna), antennular nerves and pereiopod nerves (Table 1).

Mild, moderate or severe nerve lesions were present in intact antennules and antennae. However, lesions in pereiopods were more common and severe in partially amputated, compared with intact, appendages (Table 2).

\section{Eyes}

Mild to severe, acute to chronic inflammatory lesions, often bilateral, were seen in eyes of most clinically affected prawns. In acutely affected eyes, there was moderate to severe multifocal degeneration and necrosis of retinular cells and their axons in the fasciculated zone (Fig. 5). The nuclei of affected retinular cells were karyorrhectic and their axons markedly swollen, often into a series of fusiform structures distended with either basophilic or eosinophilic amorphous material. There was associated diffuse congestion and oedema of the fasciculated zone and lamina ganglionaris, with sequestration of haemocytes in vessels and subsequent infiltration into affected areas.

In subacute to chronically affected eyes, surviving retinular cells in contiguous ommatidia appeared to aggregate into new groupings, resulting in formation

Table 1. Penaeus monodon. Frequency of occurrence and severity of lesions in selected peripheral nerves in clinically affected prawns; appendage status (partially amputated or intact) was not recorded. NVL: no visible lesion; prox.: proximal, within the cephalothorax; dist.: distal, within the appendage

\begin{tabular}{|lccccc|}
\hline \multirow{2}{*}{$\begin{array}{l}\text { Peripheral } \\
\text { nerve }\end{array}$} & \multirow{2}{*}{$\begin{array}{c}\text { No. of nerves } \\
\text { examined } \\
\text { (no. of prawns) }\end{array}$} & NVL & Mild & Moderate & Severe \\
\cline { 3 - 6 } & $23(13)$ & $8(35 \%)$ & $5(22 \%)$ & $4(17 \%)$ & $6(26 \%)$ \\
\hline $\begin{array}{c}\text { Antennular } \\
\text { nerve (dist.) }\end{array}$ & $33(26)$ & $0(0 \%)$ & $3(9 \%)$ & $4(12 \%)$ & $26(79 \%)$ \\
$\begin{array}{c}\text { Antennal } \\
\text { nerve (prox.) }\end{array}$ & $113(63)$ & $19(17 \%)$ & $19(17 \%)$ & $22(19 \%)$ & $53(47 \%)$ \\
$\begin{array}{c}\text { Antennal } \\
\text { nerve (dist.) } \\
\begin{array}{c}\text { Pereiopod } \\
\text { nerve (dist.) }\end{array}\end{array}$ & $64(14)$ & $21(33 \%)$ & $20(31 \%)$ & $8(13 \%)$ & $15(23 \%)$ \\
\hline
\end{tabular}


Table 2. Penaeus monodon. Occurrence and severity of nerve lesions in macroscopically intact or partially amputated appendages from clinically affected prawns. NVL: no visible lesion

\begin{tabular}{|lccccc|}
\hline \multirow{2}{*}{ Site } & \multirow{2}{*}{$\begin{array}{c}\text { No. of sites } \\
\text { examined }\end{array}$} & NVL & Mild & Moderate & Severe \\
\cline { 3 - 6 } & & 8 & 5 & 4 & 4 \\
Antennular nerve $^{\mathrm{a}}$ & 21 & 1 & 3 & 1 & 0 \\
Antennal nerve $^{\mathrm{a}}$ & 5 & 9 & 5 & 1 & 0 \\
Pereiopod nerve $^{\mathrm{a}}$ & 15 & 0 & 0 & 1 & 8 \\
Pereiopod nerve $^{\mathrm{b}}$ & 9 & & & & \\
${ }^{\text {a Intact (non-amputated) appendage }}$ & & & & \\
bartially amputated appendage & & & & \\
\hline
\end{tabular}

of bizarre, often bifurcated rhabdoms (Fig. 6). In the fasciculated zone, dilated blood vessels and interstitial aggregations of haemocytes were present in sites formerly occupied by necrotic axons. There was often locally extensive to diffuse accumulation of proteinaceous fluid between crystalline tracts, with aggregations of haemocytes and retinular cell debris adjacent to the retinular cell layer. In more severe, advanced cases there was fragmentation and liquefaction of those crystalline tracts overlying areas of retinular cell necrosis. In 'end-stage' eyes, most retinular cells, together with their rhabdoms and fascicles, had been lost and crystalline tracts had been replaced by fluid, cell debris and haemocytes. In these cases, cones and cone cells, together with epicorneagenous cells, were necrotic. These necrotic ommatidial structures were contained only by the overlying cuticle, which had ruptured in some cases. No significant lesions were recognised in other parts of the eye or eyestalk, including endocrine organs.

\section{Central nervous system}

Degenerative and necrotic lesions in nerve fibres and associated glial cells, identical to those seen in peripheral nerves, were often present in antennal nerve root and other unidentified nerve tracts within or adjacent to the supraoesophageal ganglion. There was associated mild to severe perivascular haemocyte aggregations in the neuropil, most obvious in areas adjacent to affected nerve tracts. Similar, but less severe, lesions were seen occasionally in ventral nerve cord ganglia. Although most central nervous system neurons appeared histologically normal, occasional

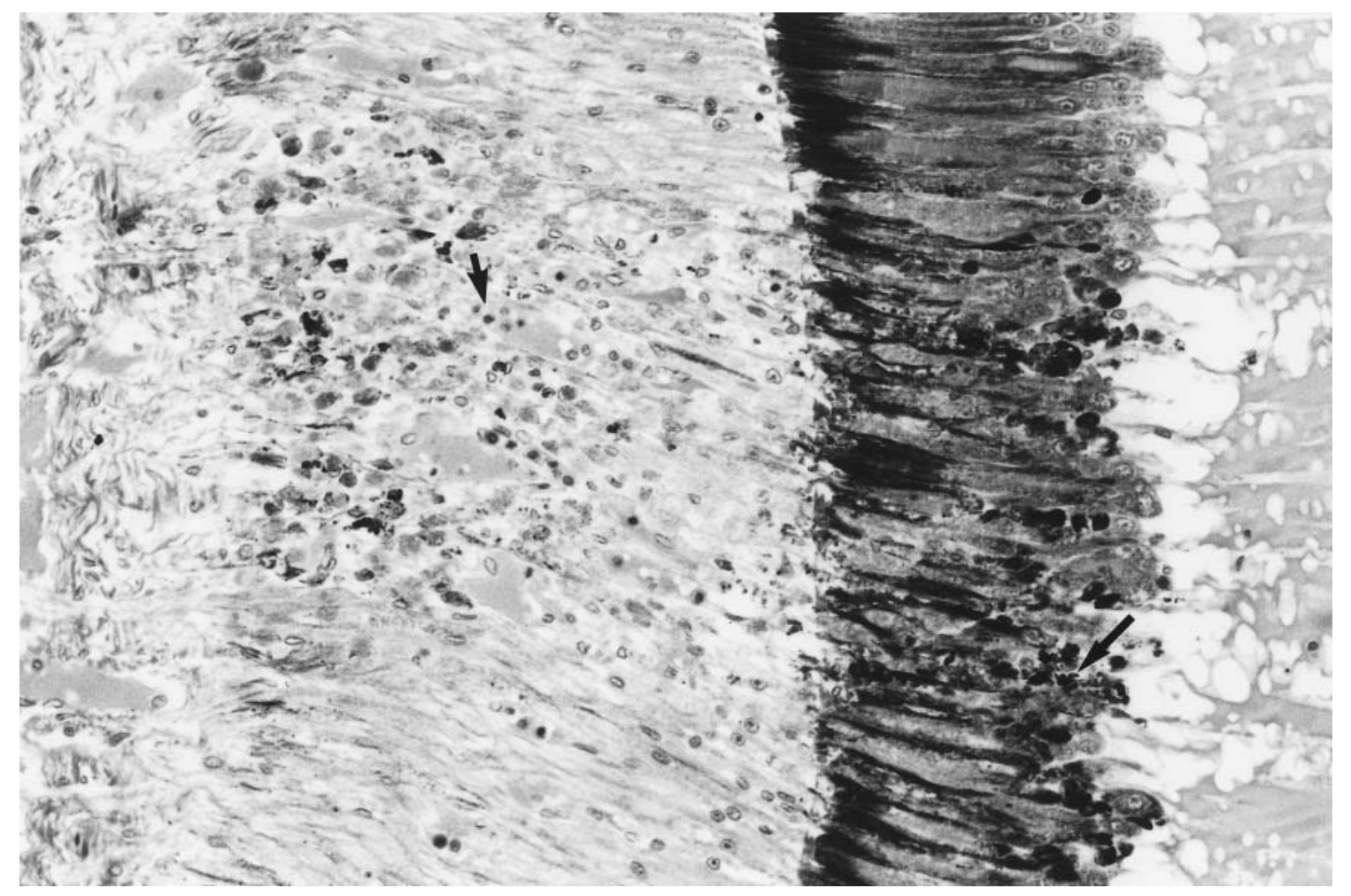

Fig. 5. Penaeus monodon. Retinopathy, showing acute, severe multifocal degeneration and necrosis of retinular cells (long arrow) and their axons in the fasciculated zone. Note the sequestration of haemocytes in vessels (short arrow) and subsequent infiltration into affected areas $(\mathrm{H} \& \mathrm{E}, \times 300)$ 
cells appeared swollen with apparently fragmenting nuclei, suggesting degenerative and necrotic changes. No significant lesions were seen in optic tracts, circumoesophageal connectives or ventral nerve cord tracts.

Other organs

Typically, lesions were present in the lymphoid organ and male genital tract of affected prawns. There was a moderate to marked increase in spheroid numbers in the lymphoid organ, with scattered single cell necrosis within spheroids. In the vas deferens, there was moderate to severe, focal to locally extensive epithelial necrosis, with subsequent ulceration and sloughing of necrotic debris into the lumen.

Aside from the apparently phagocytosed nuclear remnants seen occasionally in peripheral nerve lesions, no inclusion bodies or evidence of other aetiological agents were seen associated with lesions in nervous system, eyes, lymphoid organs or male genital tracts. No significant lesions were seen in other organs of moribund prawns, including the gills.

Mild to severe lesions consistent with PNR were seen in 2 of 5 prawns with minor clinical abnormalities apparently unrelated to PNR collected from Pond 9 and in 5 of 12, 6 of 10 and 2 of 4 similarly affected prawns collected from Ponds 24, 25 and 26, respectively. No significant lesions were seen in remaining prawns in these groups.

\section{Immunohistochemistry}

Degenerating and necrotic cells stained positively with both Y-18 and Y19 in all peripheral nerve lesions examined, including those in the eye (Fig. 7a,b). By contrast, histologically unaffected areas of peripheral nerves, eyes and central nervous systems, always stained negative (Fig. 7a,b), except for positive staining in some apparently normal neurons in medulla externa in the eyestalk (Fig. 7c). Staining within lesions was of moderate to strong intensity with Y-18 but generally stronger with Y19. The reaction was often variable, especially with $Y-18$, with some cells and areas staining moderately to strongly and others lightly or not at all. With Y-19, staining reactions in the eyes were strong, associated with lesions and clearly distinct from the naturally occurring brown, granular pigment commonly present. Lymphoid organ spheroid cells stained with moderate to heavy intensity in all prawns examined, but there was little staining in tubules (Fig. 7d). In the vas deferens, cells in and

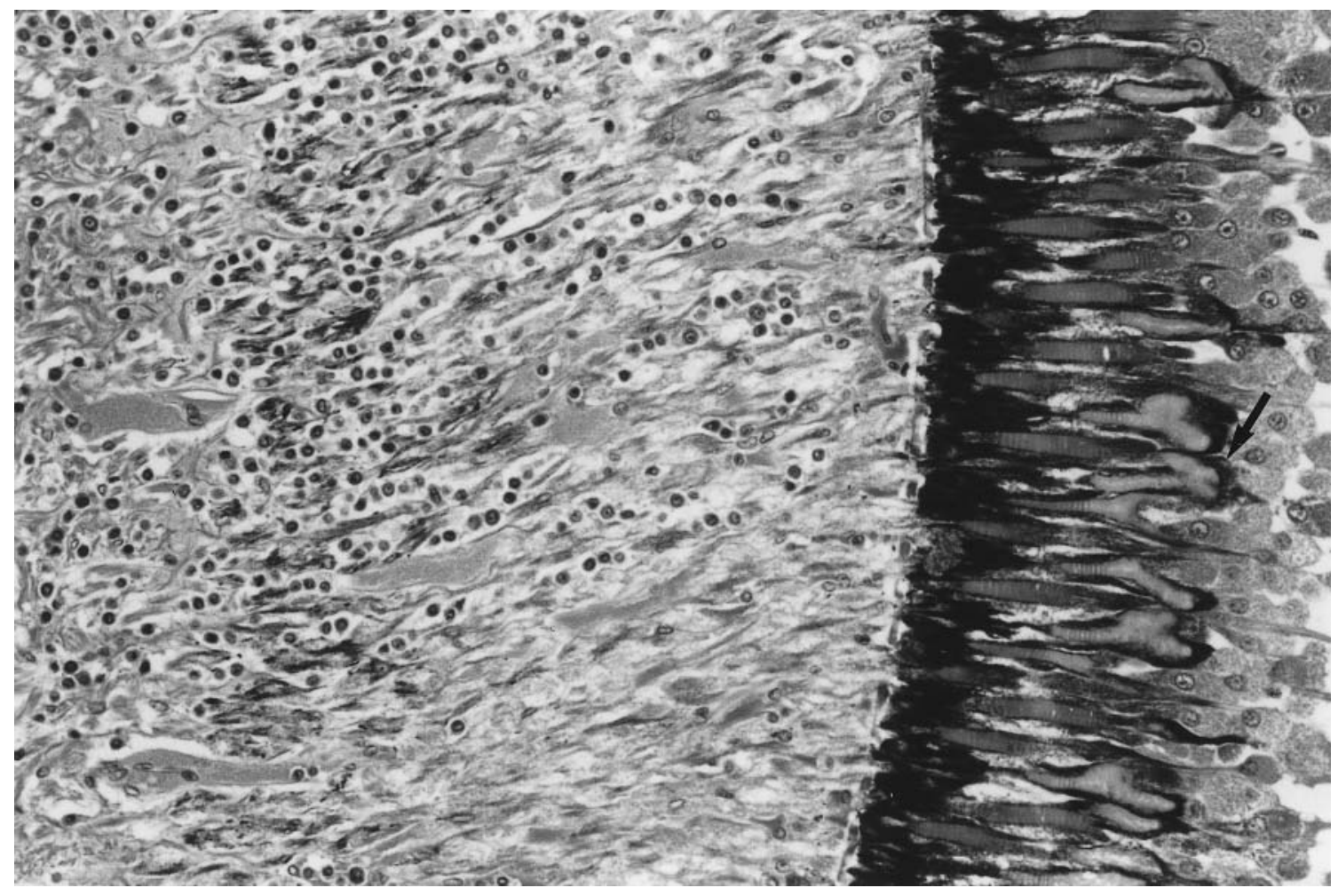

Fig. 6. Penaeus monodon. Retinopathy, showing lesion in which retinular cells in contiguous ommatida appear to have fused to form bizarre, often bifurcated rhabdoms (arrow). Note the vascular dilations and marked haemocyte infiltration in areas of the fasciculated zone formerly occupied by necrotic axons. (H\&E, $\times 300)$ 

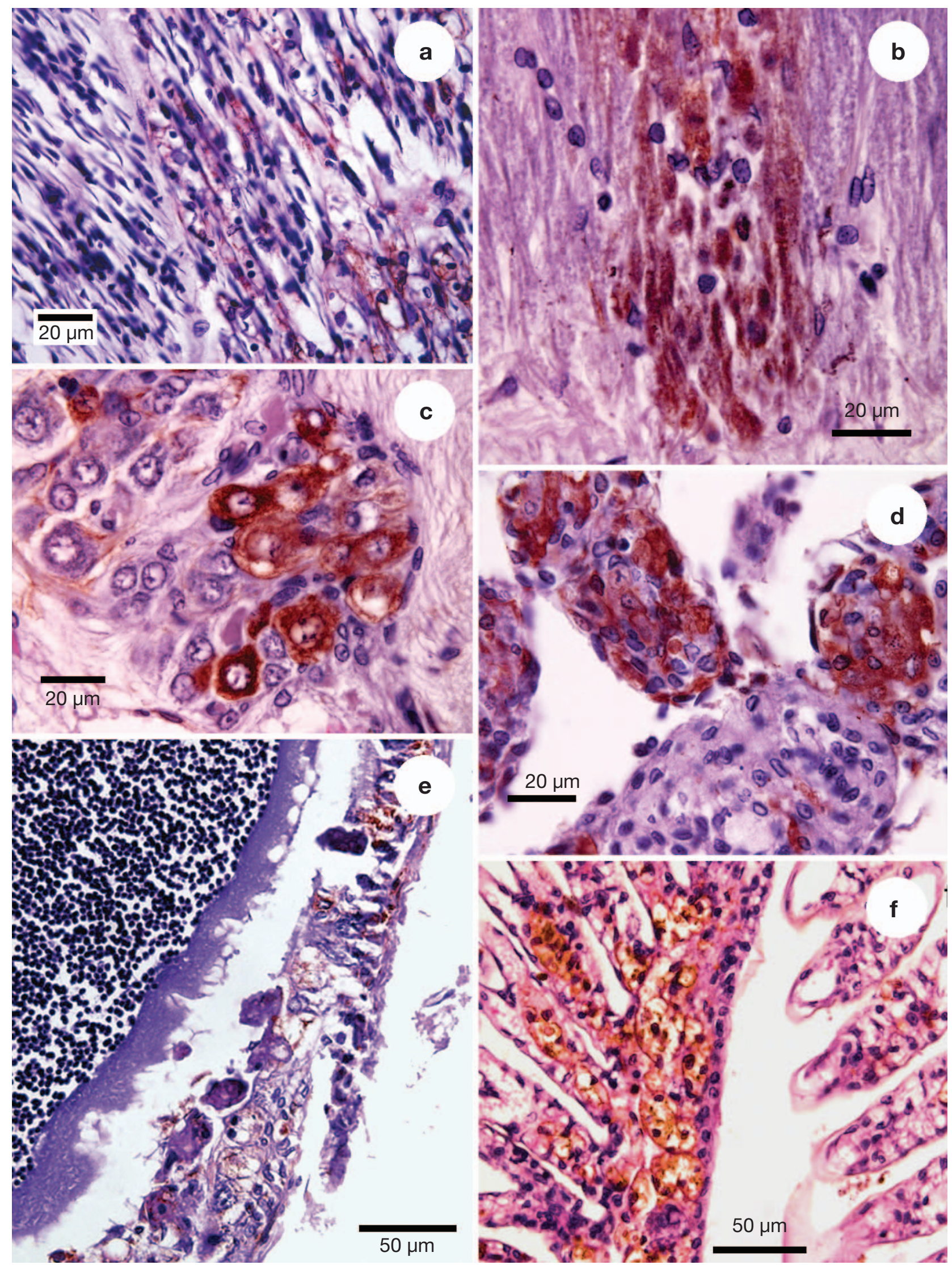


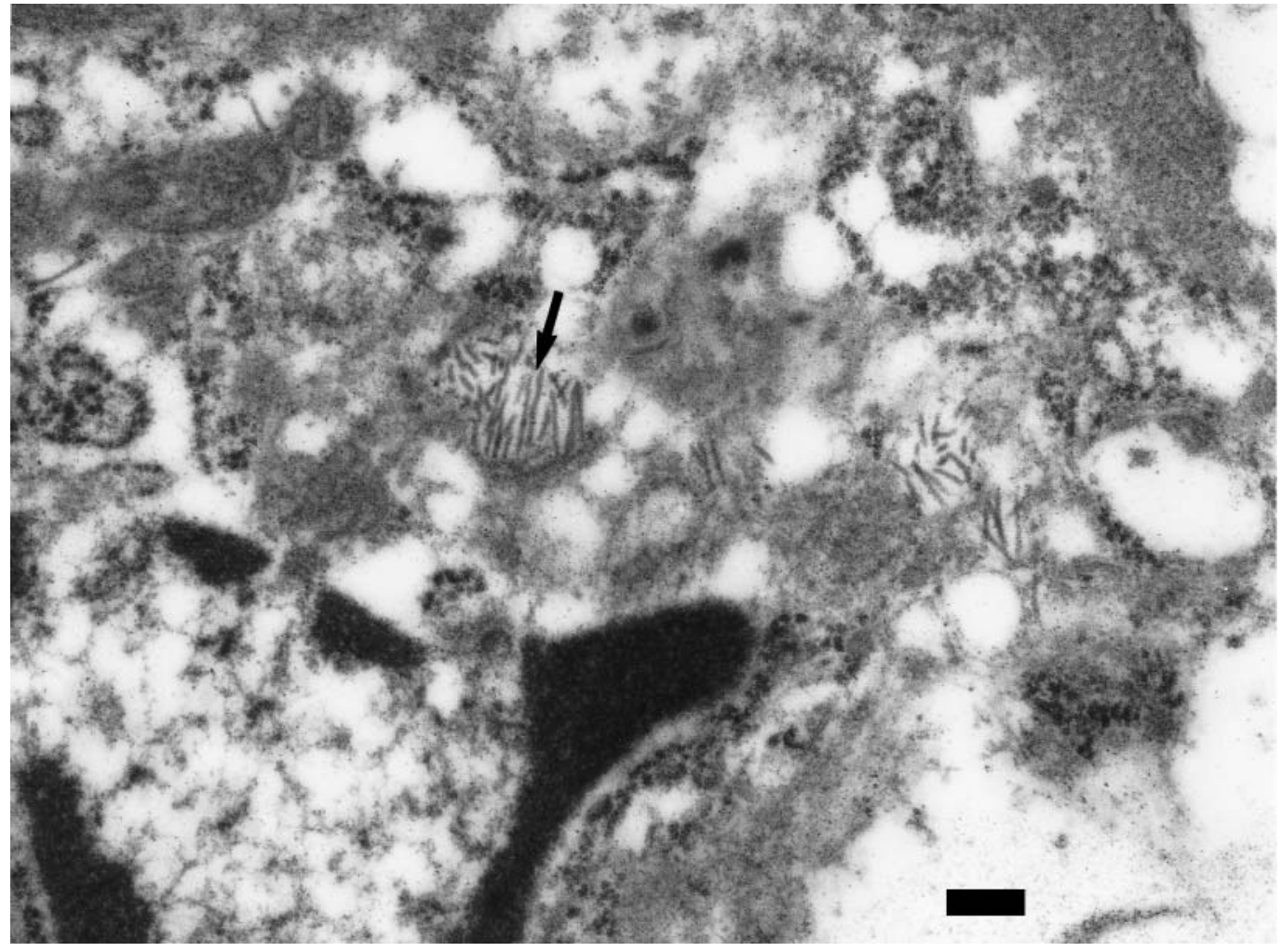

Fig. 8. Penaeus monodon. Intracytoplasmic nucleocapsids (arrow), morphologically consistent with gill-associated virus (GAV), in a putative glial cell in the antennal nerve. Scale bar $=200 \mathrm{~nm}$

around degenerating and necrotic epithelial foci showed light to strong staining; staining was not seen in unaffected areas, including sperm (Fig. 7e). Small to moderate numbers of histologically normal cells in the antennal gland epithelium and in connective tissue associated with heart, subcutis, gills (Fig. 7f), hepatopancreas, testis and ovary also stained positively.

\section{Transmission electron microscopy}

Moderate to large numbers of intracytoplasmic, rod-shaped, helical nucleocapsids and enveloped virions, morphologically consistent with GAV (Spann et al. 1997), were present in a putative glial cell in the antennal nerve root, in an unidentified cell in the fasciculated zone of the eye, as well as in putative sensory nerve cells in the antennule (Figs. 8 \& 9). Representative nucleocapsids and enveloped virions measured 105-358 × 13-16 nm and 158-184 × 42-47 $\mathrm{nm}$, respectively. No other virus-like particles were recognized.

\section{Bacteriology}

No bacteria were recovered from the haemolymph of 5 moribund prawns cultured on TCBS agar.

Fig. 7. Penaeus monodon. Tissue sections from PNR-affected prawns immunostained with MAb Y-18 or Y-19 and counterstained with H\&E showing positive (brown) reactions to a yellow head-related virus. (a) Peripheral nerve showing a positive reaction in the right tract, where a lesion is present but not in the left tract with no lesion (Y-18); (b) fasciculated zone of the eye showing a positive reaction associated only with the lesion (Y-19); (c) eyestalk medulla externa showing some positively stained nerve cells that otherwise appear normal (Y-19); (d) lymphoid organ showing positive reactions to most cells of 3 spheroids (upper part of photomicrograph) but only occasional cells in the tubule at the bottom of the photomicrograph (Y-19); (e) vas deferens showing a positive reaction in the epithelium but a negative reaction in sperm; (f) gills showing a positive reaction (Y-18) 


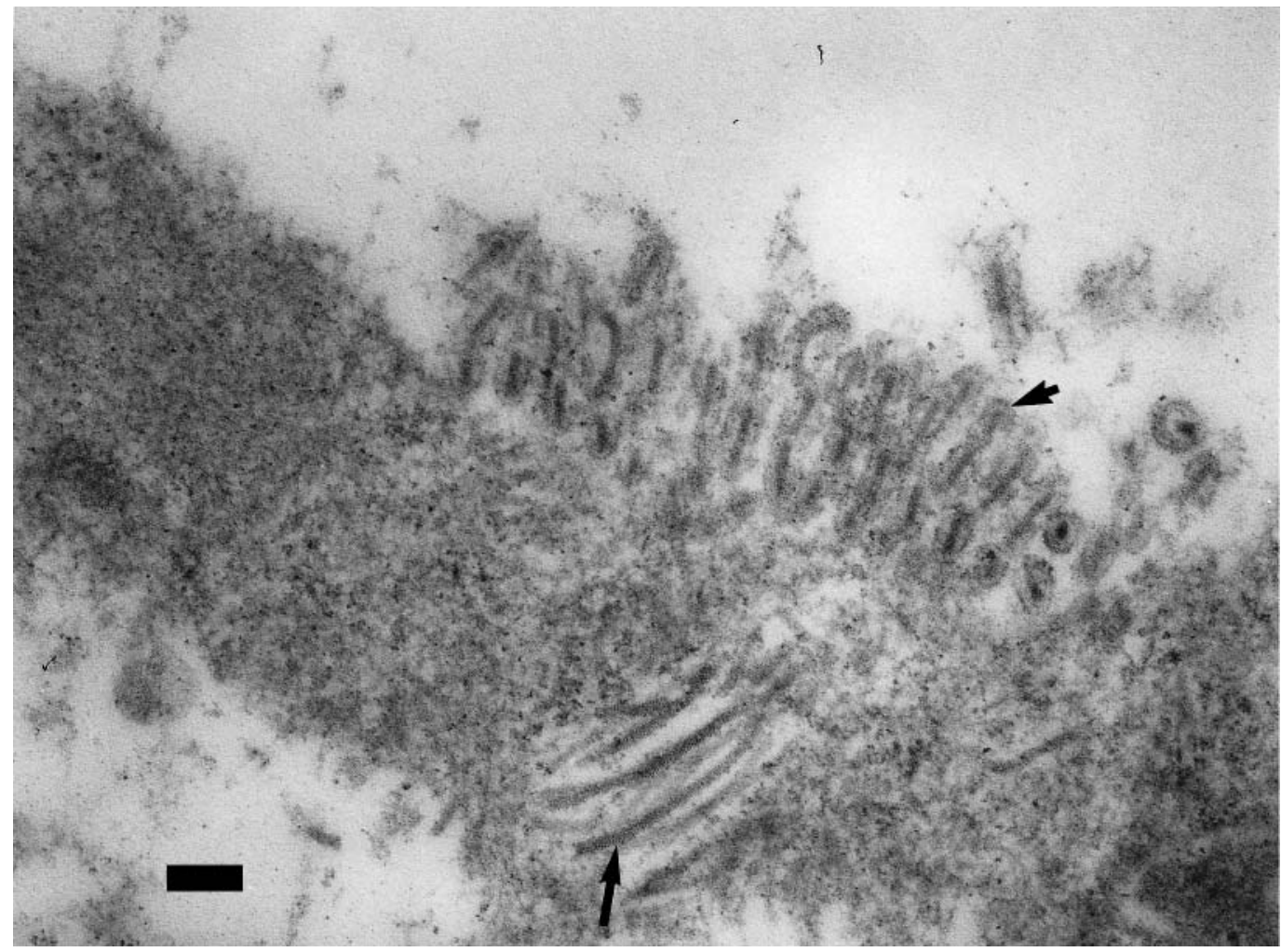

Fig. 9. Penaeus monodon. Nucleocapsids (long arrow) and enveloped virions (short arrow), morphologically consistent with GAV, in an unidentified cell in the fasciculated zone of an eye. Scale bar $=100 \mathrm{~nm}$

\section{DISCUSSION}

Moribund Penaeus monodon collected during the current study were affected with a new disease, designated PNR, which has until now been only partly characterised. In a study of diseases affecting the eyes of farmed $P$. monodon in eastern Australia, Smith (2000) examined prawns from several outbreaks, including that described in the current study. He reported degenerative and necrotic eye lesions consistent with those reported in this paper and demonstrated a rodshaped virus morphologically consistent with a GAVlike virus in the lesions.

Most peripheral nerves in crustaceans contain both motor and sensory fibres. Sheathing around axons is dependent on size; small axons lack glial cells, while larger axons possess a glial sheath that increases in size and complexity as the axon diameter increases. Motor nerve cell bodies are located in the appropriate central nervous system (CNS) ganglion and their axons travel within peripheral nerves to the target muscles. In contrast, sensory nerve cell bodies are usually located at the periphery, their dendrites are associated with an accessory structure and their axons travel to the CNS to contribute to the ganglionic neuropil (Nordlander \& Singer 1973, Govind 1992). Evidence in the current study, although inconclusive, suggested that both sensory and motor fibres in peripheral nerves were affected, except for giant motor fibres, which always appeared normal. For example, severe lesions apparently involving most fibres were not uncommon in pereiopod nerves that carry both sensory and motor fibres (Young 1959).

Lesions in peripheral nerve fibres in the current study have some features in common with Wallerian degeneration as described in vertebrates (Summers et al. 1995) and in crustaceans (Nordlander \& Singer 1973, Bittner \& Johnson 1974). Wallerian degeneration in the isolated nerve segment typically occurs when nerves are cut or when the nerve cell body dies. When crustacean nerves arising from ganglia are cut, the peripheral segment contains proximal portions of sensory axons and distal portions of motor axons, while the central stump contains the distal portions of sensory axons and the proximal portions of motor axons. Studies involving several crustacean species show that isolated sensory axonal segments usually undergo Wallerian-type degeneration within $20 \mathrm{~d}$ of transection 
(Nordlander \& Singer 1973). Initially, vesicles appear in the axoplasm which subsequently becomes more dense and compact, and is finally phagocytosed by glial cells. Later, axonless sheaths are filled with apparently normal glial cells. In the current study, however, degenerative changes in many cases preceded partial appendage amputation and glial cells in affected segments were consistently apoptotic; glial cell proliferation was never seen. These findings indicate, therefore, that partial amputation was not the primary insult in affected nerves and, when present, did not contribute significantly to lesion severity.

It is likely that the peripheral nerve and eye lesions consistently present in affected prawns would, as they progressed in severity, have seriously impaired the host's sensory and motor capabilities. Given the absence of other significant lesions in affected prawns, it follows that these PNR lesions were the probable underlying cause of the observed clinical signs and macroscopic lesions, i.e. lethargy, appendage loss, epibiotic fouling and mortalities.

The findings of our study findings strongly suggest that a virus morphologically and immunologically similar to viruses in the yellow head group is the causative infectious agent of PNR. The only such virus so far described form Australia is GAV (Cowley et al. 1999, 2000). Virions morphologically consistent with a GAV-like virus were demonstrated by TEM of affected areas of nerves and eyes, although it could be argued that such infection was coincidental, given that prevalence of GAV infection in wild and farmed Penaeus monodon populations in eastern Australia is high (Walker et al. 2001). However, the consistent demonstration by immunohistochemistry of a YHV-like virus in lesions in eyes and peripheral nerves, but no evidence of such a virus in histologically normal tissues in these organs makes a primary causal relationship highly probable.

Although YHV, the causal infectious agent of yellow head disease, is morphologically similar and genetically closely related to GAV, the two are recognised as separate viruses with distinct geographic distributions (Cowley et al. 1999). Australia is considered free of YHV, while GAV infection is endemic in eastern Australia (Spann et al. 1997, Cowley et al. 1999, Walker et al. 2001). It is therefore highly likely that the virus demonstrated by immunohistochemistry and by TEM in PNR lesions was GAV, and not YHV, even though the monoclonal antibodies we used were developed from YHV. Moreover, the distribution of lesions in PNR differed markedly from that reported for YHD, in which there is generalised, severe, multifocal to diffuse necrosis, principally in the lymphoid organ, cuticular epithelium and gills. Basophilic, usually spherical, perinuclear inclusion bodies occur in affected cells in these sites with YHD. Inclusion bodies, as well as positive staining with a YHV gene probe, have also been reported in connective tissue cells in several organs, including nerve tracts in YHD-affected prawns (Lightner 1996, Tang \& Lightner 1999). Aside from apparently phagocytosed nuclear remnants seen occasionally in peripheral nerve lesions, inclusion bodies were not seen in the current study.

It remains possible, however, that GAV infection and resultant PNR lesion induction is secondary or opportunistic, and requires prior or concurrent exposure of prawns to a separate primary insult, such as localised or systemic infection by SMV (Owens et al. 1998 ) or some other currently unrecognised viral pathogen. The description by Smith (2000) of vesicles and enveloped particles of 2 possible viruses distinct from GAV in TEM of PNR eye lesions lends some support to this suggestion. However, we did not see such particles in our TEM preparations, nor were there any other lesions present that might reasonably be attributed to an additional viral infection or other insult. It is true that immunohistochemical staining with Y-18 was most intense in the lymphoid organ and sometimes lighter or more variable in the peripheral nerve lesions than would be expected given their severity. These differences were not seen with Y-19, which gave generally more intense, even reactions. Thus, the difference in staining with Y-18 and Y-19 was probably due to different degrees of cross-reactivity for the two or the quantity of a specific viral antigen present in a particular tissue, rather than an absence or variable quantity of target virus. In addition, evidence so far suggests little divergence (typically around 1\%) in nucleotide sequences amongst viruses within the Australian GAV group (Cowley et al. 2000). Therefore, the simplest explanation of our results is that GAV is the causative agent of PNR. However, final confirmation will require results from transmission trials using GAV-free prawns and genomic characterizaton of the virus.

Since 1994, significant losses during the second half of the growout period on Australian Penaeus monodon farms have often been attributed to MCMS, which in turn has been associated with infection by GAV or SMV. However, only non-specific clinical signs and gross pathological changes (generally consistent with those seen in the current study) together with minor histopathological lesions, have been described for MCMS. Spann et al. (1997) attributed P. monodon mortalities on 4 Queensland farms to GAV infection. Diseased prawns, of typically 8 to $15 \mathrm{~g}$, congregated at pond edges, were lethargic and anorectic, with reddish body colouration and discoloured gills. Histologically, lymphoid organs of most appeared disorganised, 
lacked normal tubule structure and contained foci of GAV-infected and necrotic cells. Scattered areas of lamellar fusion, nuclear and cellular hypertrophy, and focal cell necrosis were reported in gills (Spann \& Lester 1997, Spann et al. 1997). Peripheral nerves or eyes were not examined. The clinical signs, macroscopic appearance and lymphoid organ lesions described by these workers were generally similar to those found in moribund prawns in the current study, but with some differences. For example, we saw that the MAb reaction was confined mostly to the lymphoid organ spheroids and that the tubules still had normal structure. In addition, we rarely saw lesions in the gills, either macroscopically or by histopathological examination, even thought they did give strong immunohistological reactions to Y-19.

Our findings raise the possibility that peripheral nerve and eye lesions are common in GAVassociated disease outbreaks and in MCMS more generally, but have not been reported in previous studies (Spann et al. 1997, Young 1997, Owens et al. 1998). We found that approximately $50 \%$ of prawns with minor clinical abnormalities had pathognomonic lesions of PNR up to $7 \mathrm{wk}$ before outbreaks were recognized in ponds. If PNR is attributable to GAV infection, early lesion detection would substantially improve the ability to forecast disease outbreaks currently grouped within MCMS. Epidemiological questions have been discussed in a separate paper (Callinan \& Jiang 2003).

The findings also have important implications for quarantine. Walker et al. (2001) suggested that GAV infection may be transmitted vertically and reported the observation of GAV virions in seminal fluid of infected prawns. Our demonstration by immunohistochemistry of a GAV-like virus in epithelial lesions of the vas deferens of PNR-affected prawns suggests a possible source of these virions. The prevalence of GAV infection in healthy wild-caught Penaeus monodon broodstock from northern Queensland is close to $100 \%$ (Walker et al. 2001). This high rate of infection and the probable association between GAV and PNR production losses in farmed $P$. monodon derived from such broodstock makes adoption of appropriate risk management strategies imperative.

Acknowledgements. This study was funded in part by the Australian Centre for International Agricultural Research under FIS/97/125 and by the National Center for Genetic Engineering and Biotechnology (BIOTEC), National Science and Technology Development Agency, Thailand. We thank management and staff at the study farm for their enthusiastic cooperation, Nichole Murray (NSW Agriculture), Rick Webb and Rob Gould (Centre for Microscopy and Microanalysis, University of Queensland) for excellent technical assistance, and Paisarn Sithigorngul (Department of Biology, Faculty of Science, Srinakarinwirot University, Bangkok) for providing the monoclonal antibodies used. We also thank Ian Anderson, Alex Hyatt, Leigh Owens, David and Renate Sandeman and Peter Walker for helpful discussions and advice.

\section{LITERATURE CITED}

Bell TA, Lightner DV (1988) A handbook of normal penaeid shrimp histology. World Aquaculture Society, Baton Rouge, LA

Bittner GD, Johnson AL (1974) Degeneration and regeneration in crustacean peripheral nerves. J Comp Physiol 89: $1-21$

Callinan RB, Jiang L (2003) Fatal, virus-associated peripheral neuropathy and retinopathy in farmed Penaeus monodon in eastern Australia. II. Outbreak descriptions. Dis Aquat Org 53:195-202

Cowley JA, Dimmock CM, Wongteerasupaya C, Boonsaeng V, Panyim S, Walker PJ (1999) Yellow head virus from Thailand and gill-associated virus from Australia are closely related but distinct prawn viruses. Dis Aquat Org 36:153-157

Cowley JA, Dimmock CM, Spann KM, Walker PJ (2000) Detection of Australian gill-associated virus (GAV) and lymphoid organ virus (LOV) of Penaeus monodon by RTnested PCR. Dis Aquat Org 39:159-167

Govind CK (1992) Nervous system. In: Harrison FW, Humes AG (eds) Microscopic anatomy of invertebrates, Vol 10, Decapod Crustacea. Wiley-Liss, New York, p 395-438

Lightner DV (ed) (1996) A handbook of pathology and diagnostic procedures for diseases of penaeid shrimp. The World Aquaculture Society, Baton Rouge, LA

Munday BL, Owens L (1998) Viral diseases of fish and shellfish in Australian mariculture. Fish Pathol 33:193-200

Nordlander RH, Singer M (1973) Degeneration and regeneration of severed crayfish sensory fibres: an ultrastructural study. J Comp Neurol 152:175-192

Owens L, Haqshenas G, McElnea C, Coelen R (1998) Putative spawner-isolated mortality virus associated with mid-crop mortality syndrome in farmed Penaeus monodon from northern Australia. Dis Aquat Org 34:177-185

Sithigorngul P, Chauychuwong P, Sithigorngul W, Longyant S, Chaivisuthangkura P, Menasveta P (2000) Development of a monoclonal antibody specific to yellow head virus (YHV) from Penaeus monodon. Dis Aquat Org 42:27-34

Sithigorngul P, Rukpratanporn S, Longyant S, Chaivisuthangkura P, Sithigorngul W, Menasveta P (2002) Monoclonal antibodies specific to yellow-head virus (YHV) of Penaeus monodon. Dis Aquat Org 49(1):71-76

Smith PT (2000) Diseases of the eye of farmed shrimp Penaeus monodon. Dis Aquat Org 43:159-173

Spann KM, Lester RJG (1997) Viral diseases of penaeid shrimp with particular reference to four viruses recently found in shrimp from Queensland. World J Microbiol Biotechnol 13:419-426

Spann KM, Cowley JA, Walker PJ, Lester RJG (1997) A yellow-head-like virus from Penaeus monodon cultured in Australia. Dis Aquat Org 31:169-179

Summers BA, Cummings JF, de Lahunta A (1995) Veterinary neuropathology. Mosby, St. Louis, MO

Tang KF, Lightner DV (1999) A yellowhead virus gene probe: nucleotide sequence and application for in situ hybridisation. Dis Aquat Org 35:165-173

Walker PJ, Cowley JA, Spann KM, Hodgson RA, Hall MR, Withyachumnarnkul B (2001) Yellow head complex 
viruses: transmission cycles and typo-geographical distribution in the Asia-Pacific region. In: Browdy CL, Jory DE (eds) The new wave, Proceedings of the Special Session on Sustainable Shrimp Culture. The World Aquaculture Society, Baton Rouge, LA, p 292-302

Young JH (1959) Morphology of the white shrimp Penaeus

Editorial responsibility: Timothy Flegel,

Bangkok, Thailand setiferus (Linnaeus 1758). Fish Bull US Fish Wildl Serv 59: $1-168$

Young ND (1997) A histopathological survey investigating a new disease syndrome in the giant tiger prawn (Penaeus monodon) in north Queensland Australia. Honours thesis, James Cook University of North Queensland, Townsville

Submitted: July 27, 2001; Accepted: July 12, 2002

Proofs received from author(s): February 17, 2003 